WHAT IS PHILOSOPHY? 
This page intentionally left blank 
Crossing Aesthetics

Werner Hamacher

Editor 
Translated by Lorenzo Chiesa

Stanford

University

Press

Stanford,

California

2018 


\section{WHAT IS PHILOSOPHY?}

Giorgio Agamben 


\section{Stanford University Press \\ Stanford, California}

English translation (C) 2018 by the Board of Trustees of the Leland Stanford Junior University. All rights reserved.

What Is Philosophy? was originally published in Italian in 2016 under the title Che cos'è la filosofia? (C) 2016 by Giorgio Agamben. Originally published by Quodlibet Srl., Macerata, Italia. This book was negotiated through Agnese Incisa Agenzia Letteraria, Torino.

No part of this book may be reproduced or transmitted in any form or by any means, electronic or mechanical, including photocopying and recording, or in any information storage or retrieval system without the prior written permission of Stanford University Press.

Printed in the United States of America on acid-free, archival-quality paper

Library of Congress Cataloging-in-Publication Data

Names: Agamben, Giorgio, 1942- author. Title: What is philosophy? / Giorgio Agamben ; translated by Lorenzo Chiesa.

Description: Stanford, California : Stanford University Press, 2017. I Series: Meridian: crossing aesthetics I Originally published in Italian in 2016 under the title Che cos'è la filosofia? I Includes bibliographical references and index. I

Identifiers: LCCN 2017008916 (print) | LCCN 2017011540 (ebook) | ISBN 9781503602205 (cloth :alk. paper) I ISBN 97815036022I2 (pbk. :alk. paper) I ISBN 9781503604056 (ebook) |

Subjects: LCSH: Philosophy. I Language and languages_-Philosophy. Classification: LCC B87 (ebook) I

LCC B87 .A4613 2017 (print) I DDC 100—dc23 $\mathrm{LC}$ record available at https://lccn.loc.gov/2017008916 